\title{
Influence of Proinflammatory Cytokine Gene Polymorphism on CHILDHOOD OBESITY
}

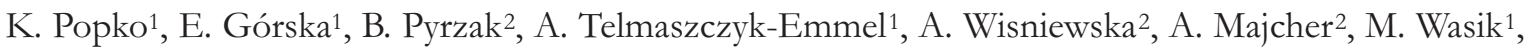 \\ U. Demkow ${ }^{1}$ \\ ${ }^{1}$ Department of Laboratory Diagnostics and Clinical Immunology of Developmental Age and \\ ${ }^{2}$ Clinic of Pediatric Endocrinology, Warsaw Medical University, Warsaw, Poland
}

\begin{abstract}
Background: Obesity development is a complex process which can be influenced by genetic predisposition modified by environmental factors. Nowadays, the problem of overweight and obesity, including related complications, occurs in increasingly younger children. Thus, there is a need for new genetic markers of increased risk of excessive body mass.

Objective: The aim of the present study was to examine the relation between polymorphisms located in promoter regions of IL-1beta, IL-6, and TNF-alpha genes and obesity development in children. Fifty obese and 55 normal weighing children were enrolled into the study. Genetic examination was performed using PCR-RFLP technique.

Results: We found a relation between G174C polymorphism in IL-6 gene and G308A in TNF-alpha gene with the occurrence of obesity. Allele $A$ in G308A was more frequent in the obese group than in the control one $(\mathrm{P}=0.04)$. The presence of allele $\mathrm{C}$ in promoter region of IL-6 gene was more frequent in obese children and connected with a statistically significant increase in the sum of 10 skin fold thickness measurements $(\mathrm{P}=0.03)$.

Conclusions: The polymorphism C3954T in IL-1beta gene showed no such relation. The examined polymorphisms of proinflammatory cytokines play a role in the regulation of body mass through their influence on metabolism and energetic homeostasis.
\end{abstract}

Key words: IL-6, IL-1, gene polymorphism, diabetes, inflammatory cytokines, obesity, TNF-alpha

\section{INTRODUCTION}

Obesity and related conditions constitute one of the most important social problems in developed societies leading to increased incidence of civilization diseases. Obesity is a disorder determined multifactorially, including a significant pathophysiological role of genetic factors. Genetic constitution may influence up to $40 \%$ of obesity causes, as numerous genes influence food uptake and energy expending mechanisms $[1,2,3]$.

Obesity may be described as an energetic homeostasis disorder caused by excessive energy supply in relation to the organism's demand. In consequence, it leads to excessive energy storage in the form of fat tis- sue. Overweight and obesity are described as increase of body mass over accepted standards. The increase of body fat amount is due to the hypertrophy of adipocytes filled with triglycerides. Obesity may have various etiology. Usually, both genetic predisposition and environmental factors are involved.

A significant relation between genetic factors and obesity development was confirmed in a representative group of mono- and dizygotic twins as well as in children and their biological parents. The correlation between the mean BMI in monozygotic twins was 0.74 , while in dizygotic twins it achieved 0.32 . This evidence has led to the hypothesis that hereditariness of this feature ranges between 50 and $90 \%[4,5]$.

The genetic factors are largely modified by environmental factors, which seem to have a decisive effect on individual phenotype [2]. No single gene responsible individually and directly for obesity development has been identified. Hence, the problem should be examined as a complex relation of many genetic factors which acting simultaneously can exert specific phenotypic outcomes. Apart from rare mutations, the commonest genetic changes are gene polymorphisms. Single nucleotide change in both exons and promoter regions can lead to gene transcription abnormalities and, in consequence, to defects in protein function [6].

Proinflammatory cytokines (IL-1, IL-6, and TNF) may substantially influence obesity development and are associated with metabolic disorders such as type 2 diabetes [7]. These cytokines significantly regulate energetic homeostasis and lipid-carbohydrate metabolism [8,9]. A diverse expression of these mediators was found in subcutaneous and intraperitoneal adipocytes $[10,11]$. It is probable that the increase of proinflammatory cytokines concentration associated with obesity can be connected with polymorphic changes in genes able to modify expression of these cytokines. It has been shown that IL-6 plays a significant role in regulation of lipid metabolism and influences energy expenditure processes. G174C polymorphism site is localized in promoter region and influences IL-6 expression level $[10,12]$. TNF plays a similar role in adipose tissue metabolism. TNF concentration among others depends on polymorphic changes in TNF genes. Allele A in G308A is related with twofold higher gene expression level, what results in increase of TNF production [11]. IL-1, another proin- 
flammatory cytokine, may play a role in body mass regulation. Similarly to IL-6 and TNF, the influence of IL-1 on lipid metabolism and energetic homeostasis seems to be connected with cytokine level in the organism. Allele $\mathrm{T}$ (homozygotic) in +C3954T causes four-fold higher IL-1beta production in comparison to other alleles [8].

The aim of the present study was to evaluate the influence of polymorphism located in the promoter region of proinflammatory cytokine genes (IL-6 G174C; IL-1 C3954T; TNF-alpha G308A) on the development of obesity and related anthropomorphic characteristics in children.

\section{MATERIAL AND METHODS}

\section{SuBJECTS}

The study protocol was approved by a local Ethics Committee. All enrolled children and their parents gave informant consent for the participation in the study.

Fifty obese children with BMI (weight/height ${ }^{2}$ ) $>95$ th percentile for age and sex reference values who were sequentially recruited from an outpatient endocrinology clinic at the Warsaw Medical University Children's Hospital were enrolled into the study. The group consisted of 27 boys aged 10-17 years (mean age $13.8 \pm 0.4 \mathrm{SE}$ ) and 23 girls aged $10-17$ years (mean $13.7 \pm 0.5)$. A control group consisted of 55 children with normal weight (BMI $<85$ th percentile for age and sex reference values). The control group consisted of age-matched 27 boys and 28 girls, who underwent routine control check-ups.

\section{Genetic Tests}

Genomic DNA isolation was performed using Genomic Midi AX (A\&A Biotechnology, Gdynia, Poland). DNA fragments amplification was performed using PCR method with appropriate starters. Polymorphisms were identified using PCR-RFLP technique (see details in Table 1). PCR products were digested

Table 1. PCR conditions for each gene.

\begin{tabular}{llll}
\hline PCR stage & IL-6 & TNF & IL-1 \\
\hline Initial denaturation & $94^{\circ} \mathrm{C}$ & $94^{\circ} \mathrm{C}$ & $94^{\circ} \mathrm{C}$ \\
& $10 \mathrm{~min}$ & $3 \mathrm{~min}$ & $4 \mathrm{~min}$ \\
Denaturation & $94^{\circ} \mathrm{C}$ & $94^{\circ} \mathrm{C}$ & $94^{\circ} \mathrm{C}$ \\
& $1 \mathrm{~min}$ & $1 \mathrm{~min}$ & $30 \mathrm{~s}$ \\
Annealing & $55^{\circ} \mathrm{C}$ & $60^{\circ} \mathrm{C}$ & $63^{\circ} \mathrm{C}$ \\
& $35 \mathrm{~s}$ & $1 \mathrm{~min}$ & $30 \mathrm{~s}$ \\
Elongation & $72^{\circ} \mathrm{C}$ & $72^{\circ} \mathrm{C}$ & $72^{\circ} \mathrm{C}$ \\
& $1 \mathrm{~min}$ & $1 \mathrm{~min}$ & $30 \mathrm{~s}$ \\
Cycles number & 35 & 36 & 35 \\
Final elongation & $72^{\circ} \mathrm{C}$ & $72^{\circ} \mathrm{C}$ & $72^{\circ} \mathrm{C}$ \\
& $10 \mathrm{~min}$ & $5 \mathrm{~min}$ & $10 \mathrm{~min}$ \\
\hline
\end{tabular}

with appropriate restriction enzymes: for IL-6 G174C - LweI and for TNF-alfa G308A - NcoI (Table 2).

Table 2. Restriction enzymes digestion conditions.

\begin{tabular}{llll}
\hline Enzyme & $\begin{array}{l}\text { \# of units } \\
(\mathrm{U})\end{array}$ & $\begin{array}{l}\text { Time } \\
\text { (hours) }\end{array}$ & $\begin{array}{l}\text { Temperature } \\
\left({ }^{\circ} \mathrm{C}\right)\end{array}$ \\
\hline LweI & 1 & 24 & 37 \\
NcoI & 2 & 24 & 37 \\
TaqI & 2 & 3 & 65 \\
\hline
\end{tabular}

\section{STATISTICAL ELABORATION}

Frequency of distribution analysis was performed with Chi2 test. Significance of differences was tested with Kruskal-Wallis and Mann-Whitney U tests. Significance was accepted at $\mathrm{P}<0.05$. The results were processed statistically using Statgraphics 4.0 plus and Statistica 6.0 software. The Hardy-Weinberg equilibrium test was applied to evaluate genotype frequencies.

\section{RESULTS}

Statistical analysis of genetic data shows that two of the three examined polymorphisms correlated with the presence of obesity in children. We found differences in the frequency of G308A polymorphism in the TNF promoter region in obese children in comparison with children with a normal body mass. Allele A in G/A heterozygotes was more frequent in the obese group. A significant correlation was found in all analyzed groups $(\mathrm{P}=0.04)$ (Fig. 1)

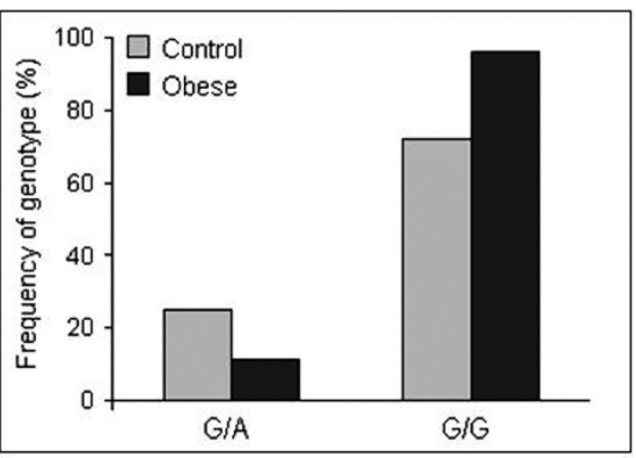

Fig. 1. Frequency of genotypes in G308A site of the TNF gene in the obese and non-obese children.

As far as G174C polymorphism in the IL-6 gene promoter is concerned, $\mathrm{C}$ allele was more frequent in obese children. The differences ranging from 10 to $20 \%$, however, were statistically insignificant. In the studied population, C3954C site in the IL-1 gene promoter analysis showed no correlation with obesity development. The analyzed polymorphisms did not significantly influence the anthropomorphic parameters, such as BMI, waist or hips circumference. However, we found that changes in G174C polymorphic site in the IL- 6 gene in obese girls were related to the sum of 10 skin fold thickness measurements. The presence of 


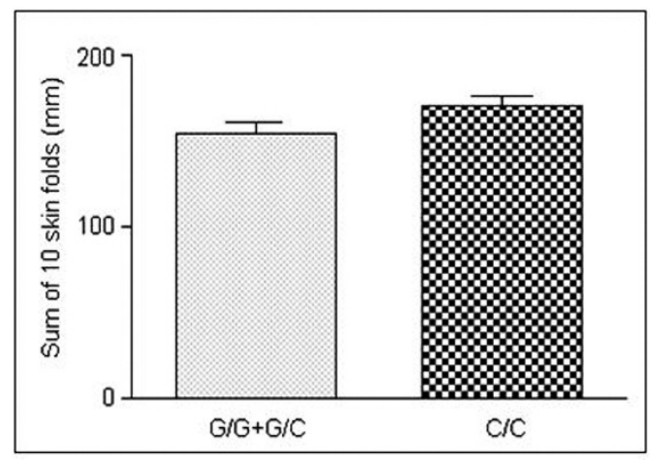

Fig. 2. Differences between the sums of 10 skin fold thickness measurements in obese girls in relation to the genotype in G174C polymorphic site.

allele $\mathrm{C}$ in the promoter region of IL- 6 gene in both $\mathrm{C} / \mathrm{C}$ homozygotes and $\mathrm{G} / \mathrm{C}$ heterozygotes was connected to a significant increase in the sum of 10 skin fold thickness measurements in obese girls $(\mathrm{P}=0.03)$ (Fig. 2).

\section{Discussion}

In the present study, we examined the relation between three genetic polymorphisms in the promoter regions of IL-1, IL- 6 , and TNF, on one hand and the obesity in children, on the other. The results seem to confirm a hypothetical relation between the IL-6 genotype and obesity development [12]. The connection between G174C polymorphism and body mass regulation is influenced by certain alleles affecting the cytokine expression levels [13]. The analyzed polymorphism is localized in the promoter region, where transcription factors frequently exert their functions. G174C polymorphism influences the energy expenditure processes in different ways. The process can be regulated centrally via the IL-6 expression in the hypothalamus. In vitro studies show that knock-out mice for IL-6 gene increased their energy expenditure rate several times after administration of exogenous IL-6 to the central nervous system. Interestingly, the phenomenon was not observed when IL- 6 was administered peripherally [14]. In humans, high level of proinflammatory cytokines (including IL-6) and their high expression in the brain lead to an increase in basal energy expenditure and may cause cachexia [15]. Peripheral administration of IL- 6 causes an increase in basal metabolic rate and in the hypothalamus-pituitary-adrenal axis activity. The increase of this activity is closely related to the administered dose of IL-6. This observation may indicate that the hypothalamic hormones, through corticotropin release, can mediate both processes [16]. The influence of IL-6 on energy expenditure can also be explained by enhanced adrenergic stimulation. It has been shown that IL-6 accelerates heart rate, increases norepinephrine level, and stimulates sympathetic nervous system, being the main efferent pathway able to regulate energy expenditure $[17,18,19]$. Moreover, sympathetic neurons are able to produce IL-6. The IL-6 receptor is expressed on their surface and hence they are susceptible to its function [20]. In patients with renal cancer, IL-6 ad- ministration causes an increase in norepinephrine level and basal energy expenditure [21]. The parallel hypothesis assumes that IL-6 function may also be enhanced by leptin [22].

Subsequently, the polymorphisms G308A in the TNF gene promoter region may influence overweight or obesity development. In obese children, A allele was significantly more frequent in comparison with the control group. A correlation between this polymorphism and obesity is probably caused by the influence of the polymorphism on cytokine expression. Some authors claim that TNF is able to impair lipid metabolism leading to hypertriglyceridemia, decreasing lipoprotein lipase activity, and inducing de novo synthesis of fatty acids in the liver [23]. Moreover, TNF is able to impair carbohydrates metabolism via decreased insulin-stimulated autophosphorylation and decreased activation of insulin-receptor tyrosine kinase in muscles and in adipose tissue $[24,25]$. This effect can be interpreted as additional evidence confirming the correlation between TNF and obesity.

The assessment of the frequency of C3954T polymorphic changes in the promoter region of IL- 1 gene showed no direct connection between the polymorphism and obesity. Here, we found no significant differences between the obese and control groups.

The mechanism of a relationship between IL-1beta gene polymorphisms and obesity development has not been unambiguously determined to-date. Some authors suggest that $\mathrm{T}$ allele heterozygotes, in +3954 site, are connected with a four-fold higher secretion of IL-1 in comparison with C/C homozygotes [26, 27]. Nevertheless, the described correlation of IL-1 and body mass seems to be caused by an indirect effect of this cytokine. The IL-1 can influence lipid metabolism indirectly [28]. IL-1 secretion is regulated by TNF synthesized by adipose tissue. An increase in TNF secretion in overgrown adipose tissue can stimulate adipocytes to produce IL-1beta. In turn, IL-1beta may influence the TNF expression and it shows a synergistic effect with TNF [29]. The effect of IL-1 on lipid metabolism depends on inhibition of lipoprotein lipase activity [30]. In vitro studies show that this cytokine is able to modify adipocytes function via inhibition of their maturation and inhibition of proteins involved in fatty acids transport within adipose tissue [31]. Another potential role of IL-1beta in obesity is related to its effect on leptin synthesis. Bruun et al. [32] found that both TNF and IL-1 are able to regulate leptin expression and secretion.

In conclusion, the examined polymorphisms of proinflammatory cytokines play a role in the regulation of body mass through their influence on metabolism and energy homeostasis. None of the analyzed factors can be used as an explicit marker of the risk for obesity. Nonetheless, mutual relations between studied cytokines (IL-1, IL-6, and TNF) concerning their expression and regulation are of great importance.

Acknowledgments: Supported by an intramural grant of Warsaw Medical University, Warsaw, Poland.

Conflicts of interest: The authors declared no conflicts of interest in relation to this article. 


\section{REFERENCES}

[1] Comuzzie AG, Blangero J, Mahaney MC, Haffner SM, Mitchell BD, Stern MP, MacCluer JW. Genetic and environmental correlations among hormone levels and measures of body fat accumulation and topography. J Clin Endocrinol Metab 1996; 81: 597-600.

[2] Maes HH, Neale MC, EaVes L. Genetic and environmental factors in relative body weight and human adiposity. Behav Genet 1997; 27: 325-351.

[3] Stunkard AJ. An adoption study of human obesity. N Engl J Med 1986; 314: 193-198.

[4] Pociot F, Molvig J, Wogensen L, Worsaae H, Nerup A. TaqI polymorphism in the human interleukin-1 beta (IL-1 beta) gene correlates with IL-1 beta secretion in vitro. Eur J Clin Invest 1992; 22: 396-402.

[5] Allison DB. The hetitability of body mass index among an international sample of monozygotic twins reared apart. Int J Obes Relat Metab Disord 1996; 20: 501-506.

[6] Popko K, Gorska E, Wasik M, Stoklosa T, Plywaczewski R, Winiarska M, Gorecka D, Sliwinski P, Demkow U. Frequency of distribution of lepton receptor gene polymorphism in obstructive sleep apnea patients. J Physiol Pharmacol 2007; 58 Suppl 5: 551-561.

[7] Fruhbeck G, Gomez-Ambrosi J, Muruzabal FJ, Burrel MA. The adipocyte: a model for integration of endocrine and metabolic signaling in energy metabolism regulation. Am J Physiol Endocrinol Metabol 2001; 280: 827-847.

[8] Grunfeld C, Feingold KR. The metabolic effects of tumor necrosis factor and other cytokines. Biotherapy 1991; 3: 143-158.

[9] Mohamed-Ali V, Pinkney JH, Coppack SW. Adipose tissue as an endocrine and paracrine organ. Int J Obes 1998; 22: 1145-1158.

[10] Fried SK, Bunkin DA, Greengerg AS. Omental and subcutaneous adipose tissue of obese subjects release interleukin-6: depot difference and regulation by glucocorticoid. J Clin Endocrinol Metabol 1998; 83: 847-850.

[11] Hube F, Birgel M, Lee YM, Hauner H. Expression pattern of tumor necrosis factor in subcutaneous and omental human adipose tissue: role of obesity and non-insulindependent diabetes mellitus. Eur J Clin Invest 1999; 29: 672-678.

[12] Popko K, Gorska E, Potapinska O, Wasik M, Stoklosa T, Plywaczewski R, Winiarska M, Gorecka D, Sliwinski P, Popko M, Szwed T, Demkow U. Frequency of distribution of cytokines IL-1, IL-6 and TNF-alfa gene polymorphism in patients with obstructive sleep apnea. J Physiol Pharmacol 2008; 59 Suppl 6: 607-614.

[13] Fishman D, Faulds G, Jeffery R, Mohamed Ali V, Yudkin YS, Humphries S, Woo P. The effect of novel polymorphism in the interleukin-6 (IL-6) gene on IL- 6 transcription and an association with systemic-onset juvenile chronic arthritis. J Clin Invest 1998; 102: 1369-1376.

[14] Wallenius V, Wallenius K, Ahren B, Rudling M, Carlsten H, Dickson SL, Ohlsson C, Jansson J-O. Interleukin-6 deficient mice develop mature-onset obesity. Nature Med 2002; 8: 75-79.

[15] Plata-Salaman CR. Central nervous system mechanisms contributing to the cachexia-anorexia syndrome. Nutrition 2000; 16: 1009-1012.

[16] Tsigos C, Papanicolaou DA, Defensor R, Mitsidis CS, Kyrou I, Chrousos GP. Dose effects of recombinant human interleukin- 6 on pituitary hormone secretion and energy expenditure. Neuroendocrinology 1997; 66: 54-62.

[17] Fernandes-Real JM, Vayreda M, Richart C, Gutierrez C, Broch M, Vendrell J, Ricart W. Circulating interleukin-6 levels, blood pressure, and insulin sensitivity in apparently healthy men and women. J Clin Endocrinol Metabol 2001; 86: 1154-1159.

[18] Papanicolaou DA, Petrides JS, Tsigos C, Bina S,
Kalogeras KT, Wilder R, Gold PW, Deuster PA, Chrousos GP. Exercise stimulates interleukin-6 secretion: inhibition by glucocorticoids and correlation with catecholamines. Am J Physiol 1996; 271: E601-E605.

[19] Torpy DJ, Papanicolaou DA, Lotsikas AJ, Wilder RL, Chrousos GP, Pillemer SR. Responses of the sympathetic nervous system and the hypothalamic-pituitary-adrenal axis to interleukin-6: a pilot study in fibromyalgia. Arthritis Rheum 2000; 43: 872-880.

[20] Marz P, Cheng JG, Gadient RA, Patterson PH, Stovan T, Otten U, Rose-John S. Sympathetic neurons can produce and respond to interleukin 6. Proc Natl Acad Sci 1998; 95: 3251-3256.

[21] Stouthard JM, Romijn JA, Van der Poll T, Endert E, Klein S, Bakker PJ, Veenhof CH, Sauerwein HP. Endocrinologic and metabolic effects of interleukin-6 in humans. Am J Physiol 1995; 268: E813-E819.

[22] Rosenbaum M, Murphy EM, Heymsfield SB, Matthews DE, Leiber RL. Low dose leptin administration reverses effects of sustained weight-reduction on energy expenditure and circulating concentrations of thyroid hormones. J Clin Endocrinol Metabol 2002; 87: 2391-2394.

[23] Feingold KR, Grunfeld C. Role of cytokines in inducing hyperlipidemia. Diabetes 1992; 41 Suppl 2: 97-101.

[24] Hotamisligil GS, Peraldi P, Budavari A, Ellis R, White MF, Spiegelman BM. IRS-1-mediated inhibition of insulin receptor tyrosine kinase activity in TNF-alfa and obesity-induced insulin resistance. Science 1996; 271: 665-668.

[25] Hotomisligil GS, Murray DL, Choy LN, Spiegelman BM. Tumor necrosis factor alpha inhibits signaling from the insulin receptor. Proc Natl Acad Sci 1994; 91: 4854-4858.

[26] Pociot F, Molvig J, Wogensen L, Worsaae H, Nerup A TaqI polymorphism in the human interleukin-1 beta (IL-1 beta) gene correlates with IL-1 beta secretion in vitro. Eur J Clin Invest 1992; 22: 396-402.

[27] Pociot F, Ronningen KS, Bergholdt R, Lorencen T, Johannesen J, Ye K. Genetic susceptibility markers in Danish patients with type 1 (insulin-dependent) diabetes-evidence for polygenicity in men. Danish Study Group of Diabetes in Childhood. Autoimmunity 1994; 19: 169-178.

[28] Fain JN, Cheema PS, Bahouth SW, Lloyd Hiler M. Resting release by human adipose tissue explants in primary culture. Biochem Biophys Res Commun 2003; 300: 674678.

[29] Zhang HH, Kumar S, Barnett AH, Eggo MC. Dexamethasone inhibits tumor necrosis factor-alpha-induced apoptosis and interleukin-1 beta release in human subcutaneous adipocytes and preadipocytes. J Clin Endocrinol Metabol 2001; 86: 2817-2825.

[30] Beutler BA, Cerami A. Recombinant interleukin-1 suppresses lipoprotein lipase activity in 3T3-L1 cells. J Immunol 1985; 135: 3969-3971.

[31] Memon RA, Feingold KR, Moser AH, Fuller J, Grunfeld C. Regulation of fatty acid transport protein and fatty acid translocase mRNA levels by endotoxin and cytokines. Am J Physiol 1998; 274: E210-E217.

[32] Bruun JM, Pedersen SB, Kristensen K, Richelsen B. Effects of pro-inflammatory cytokines and chemokines on leptin production in human adipose tissue in vitro. Mol Cell Endocrinol 2002; 190: 91-99.

Author's address:

Katarzyna Popko

Department of Laboratory Diagnostics and Clinical Immunology of the Developmental Age

Warsaw Medical University

Marszalkowska 24 St.

00-576 Warsaw, Poland

Phone: +48226296517

E-mail: aksiak@interia.pl 